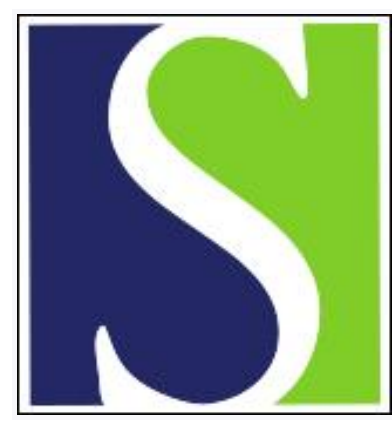

Scand J Work Environ Health 1999;25(2):100-104

https://doi.org/10.5271/sjweh.411

Issue date: Apr 1999

Relationship between shift work and onset of hypertension in a cohort of manual workers

by Morikawa Y, Nakagawa H, Miura K, Ishizaki M, Tabata M, Nishijo M, Higashiguchi K, Yoshita K, Sagara T, Kido T, Naruse Y, Nogawa K

The following articles refer to this text: $2001 ; 27(3): 161-213$;

2001;27(5):318-326; 2002;28(1):64-71; 2004;30(2):149-156;

2006;32(3):204-208; 2007;33(1):45-50; 2008;34(1):33-39;

2009;35(4):309-318; 2015;41(3):259-267; 2019;45(3):256-266

Key terms: blood pressure; follow-up study; incidence; industrial worker; shift worker

This article in PubMed: www.ncbi.nlm.nih.gov/pubmed/10360464 


\title{
Relationship between shift work and onset of hypertension in a cohort of manual workers
}

\author{
by Yuko Morikawa, PhD, ${ }^{1}$ Hideaki Nakagawa, PhD, ${ }^{1}$ Katsuyuki Miura, PhD, ${ }^{1}$ Masao Ishizaki, PhD, ${ }^{1}$ Masaji \\ Tabata, PhD, ${ }^{1}$ Muneko Nishijo, PhD, ${ }^{1}$ Kazuyo Higashiguchi, ${ }^{1}$ Katsushi Yoshita, ${ }^{1}$ Takiko Sagara, ${ }^{1}$ Teruhiko \\ Kido, PhD, ${ }^{2}$ Yuchi Naruse, PhD, ${ }^{3}$ Koji Nogawa, PhD ${ }^{4}$
}

\begin{abstract}
Morikawa Y, Nakagawa H, Miura K, Ishizaki M, Tabata M, Nishijo M, Higashiguchi K, Yoshita K, Sagara T, Kido T, Naruse $Y$, Nogawa K. Relationship between shift work and onset of hypertension in a cohort of manual workers. Scand J Work Environ Health 1999;25(2):100-104.

Objectives This study investigated the possibility of a relationship between blood pressure level and rotating 3 shift work in a prospective follow-up of workers in a zipper and aluminum sash factory in Japan.

Methods Altogether 1551 men aged 18 - 49 years were followed prospectively for 5 years, and the cumulative incidence of hypertension among 3-shift workers was compared with that of day workers. A multiple logistic analysis was used for adjusting for base-line characteristics such as age, body mass index, blood pressure, and drinking habit.

Results In the younger age group, the relative risk of the rotating 3-shift workers during the observational period was increased compared with that of day workers after adjustment for the confounding factors. In the older group, the cumulative incidence of hypertension was not higher for workers who had continued shift work. However, a relatively high risk of hypertension was found for workers who converted from 3-shift work to day work when compared with those who remained on shift work and day work.
\end{abstract}

Conclusions It is suggested that there is an association between 3-shift work and blood pressure.

Key terms blood pressure, follow-up study, incidence, industrial worker, shift worker.

Recent reports have shown an increased risk of ischemic heart disease among shift workers $(1-9)$. However, the results of studies on the relationship between shift work and the traditional risk factors of ischemic heart disease have been controversial (10-18). Some studies found elevated serum triglyceride levels or lipoproteins (1315) among shift workers, but few studies found an increase in blood pressure, serum cholesterol, and other risk factors. Selection bias is one of the greatest methodological problems when this issue is investigated (ie, the healthy worker effect) $(19,20)$. The aim of the present cohort study was to investigate the possibility of a relationship between blood pressure level and 3-shift work, with selection bias and confounding factors taken into account.

\section{Subjects and methods}

\section{Subjects}

The cohort consisted of all manual male workers ranging from 18 to 49 years of age in a Japanese zipper and sash factory. We followed the subjects from 1990 to 1995 and investigated the cumulative incidence of hypertension. All subjects with any of the following were excluded: high blood pressure in the base-line health examination [systolic blood pressure $\geq 140 \mathrm{~mm} \mathrm{Hg}(\geq 18.62 \mathrm{kPa}$ ) and diastolic blood pressure $\geq 90 \mathrm{~mm} \mathrm{Hg}(\geq 11.97 \mathrm{kPa})$, history of cardiovascular disease, diabetes, kidney disease, or any other chronic diseases]. The target population numbered 2000, and 1551 men were followed to the

Reprint requests to: Dr Yuko Morikawa, Department of Public Health, Kanazawa Medical University, 1-1, Daigaku, Uchinada-machi, Kahoku-gun, Ishikawa-ken, Japan, 920-02. 
end (table 1). The subjects who had at least 5 annual health examinations during the 5-year period were included in the analysis. The follow-up rate was $77.6 \%$.

\section{Diagnosis}

Hypertension was diagnosed on the basis of the following criteria: high blood pressure [systolic blood pressure $\geq 140 \mathrm{~mm} \mathrm{Hg}(\geq 18.62 \mathrm{kPa})$ or diastolic blood pressure $\geq 90 \mathrm{~mm} \mathrm{Hg}(\geq 11.97 \mathrm{kPa})$ or both] in the annual health examinations at least twice or the initiation of antihypertensive treatment. Blood pressure measurements were taken with a mercury sphygmomanometer from the right arm of the subjects while seated after 5 minutes of rest.

\section{Occupations}

The work schedules were 2 types, day work and rotating 3-shift work. The work schedules were taken from questionnaires administered in 1990 and 1995. Some workers who did shift work without night shifts were included in the group of day workers. In the factory, 3-shift workers were rotated counterclockwise. Two-thirds of them had a noncontinuous shift system ( 5 day shifts, 5 night shifts, and 5 evening shifts with 2 weekend rest days between successive shifts). One-third of them had a continuous shift system ( 4 day shifts, 4 night shifts, and 4 evening shifts or 3 day shifts, 3 nights shifts, and 3 evening shifts, with 1 rest day between successive shifts). Both systems changed shifts at 0800,1630 , and 0015 or 0630,1300 , and 2130. Some jobs, like operating machines which melted, heated, mixed, or casted are done by 3 -shift workers. Construction aluminum products are the jobs of day workers. Other jobs are done by both workers.

The participants were classified into 1 of 4 groups according to work conditions in 1990 and 1995: (i) "day-day" workers, men who did day work in both 1990 and 1995, (ii) "day-shift" workers, men who did day work in 1990 and transferred to rotating 3-shift work during the observation period, (iii) "shift-day" workers, men who did 3-shift work in 1990 and transferred to day work during the observation period, and (iv) shift-shift workers, men who did 3-shift work in both 1990 and 1995.

The follow-up rate of the day workers was $74.9 \%$, and that of the 3 -shift workers was $82.8 \%$, as shown in table 1 . The cause of dropout was mainly resignation from the factory, the reasons for which were unknown. Table 2 shows the base-line characteristics of the subjects and the dropouts. The base-line characteristics according to the work conditions are shown in table 3.

\section{Statistics}

We analyzed data by 3 age groups $(18-29,30-39$, and $40-49$ years). The cumulative incidence of hypertension during the 5-year period was compared between the 4 groups according to their work conditions. By a multiple logistic analysis, the relative risks of hypertension among the 3-shift workers were evaluated after adjustment for other confounding factors. Age, body mass index (BMI), systolic blood pressure, and drinking habit at the time of the base-line examination were allowed in the model. Age, BMI, and blood pressure were used as

Table 1. Follow-up rate by age and type of work schedule in 1990.

\begin{tabular}{lccc}
\hline & \multirow{2}{*}{$\begin{array}{c}\text { Number } \\
\text { at base line }\end{array}$} & \multicolumn{2}{c}{ Subjects followed } \\
\cline { 3 - 4 } & & $N$ & $\%$ \\
\cline { 2 - 4 } Age (years) & & & \\
$18-29$ & 567 & 452 & 79.7 \\
$30-39$ & 731 & 568 & 77.7 \\
$40-49$ & 702 & 531 & 75.6 \\
Type of work schedule & & & \\
Day work & 1331 & 997 & 74.9 \\
Shift work & 669 & 554 & 82.8 \\
\hline Total & 2000 & 1551 & 77.6 \\
\hline
\end{tabular}

Table 2. Comparison of the base-line characteriscs of the subjects who were followed and those who dropped out.

\begin{tabular}{|c|c|c|c|c|c|c|c|c|c|c|c|c|c|c|}
\hline \multirow[t]{2}{*}{$\begin{array}{l}\text { Type of work } \\
\text { schedule in } 1990\end{array}$} & \multirow[t]{2}{*}{$\mathrm{N}$} & \multicolumn{2}{|c|}{ Age (years) } & \multicolumn{2}{|c|}{$\begin{array}{l}\text { Length of } \\
\text { employment } \\
\text { (years) }\end{array}$} & \multicolumn{2}{|c|}{$\begin{array}{l}\text { Body mass } \\
\text { index }\end{array}$} & \multicolumn{2}{|c|}{$\begin{array}{c}\text { Systolic blood } \\
\text { pressure } \\
(\mathrm{mm} \mathrm{Hg})\end{array}$} & \multicolumn{2}{|c|}{$\begin{array}{c}\text { Diastolic blood } \\
\text { pressure } \\
\left(\mathrm{mm} \mathrm{Hg}^{\mathrm{b}}\right)\end{array}$} & \multirow[t]{2}{*}{$\begin{array}{c}\text { Habitual } \\
\text { drinking } \\
\qquad \%)\end{array}$} & \multirow[t]{2}{*}{$\begin{array}{c}\text { Current } \\
\text { smoking } \\
(\%)\end{array}$} & \multirow{2}{*}{$\begin{array}{l}\text { Lack of } \\
\text { leisure- } \\
\text { time } \\
\text { sport' }^{+}(\%)\end{array}$} \\
\hline & & Mean & SD & Mean & $\mathrm{SD}$ & Mean & SD & Mean & SD & Mean & $\mathrm{SD}$ & & & \\
\hline \multicolumn{15}{|l|}{ Day work } \\
\hline $\begin{array}{l}\text { Followed subjects } \\
\text { Dropouts }\end{array}$ & $\begin{array}{l}997 \\
334\end{array}$ & $\begin{array}{l}35.4 \\
36.0\end{array}$ & $\begin{array}{l}8.0 \\
8.5\end{array}$ & $\begin{array}{l}15.5 \\
15.8\end{array}$ & $\begin{array}{l}9.3 \\
7.9\end{array}$ & $\begin{array}{l}22.1 \\
22.4\end{array}$ & $\begin{array}{l}2.5 \\
2.6\end{array}$ & $\begin{array}{l}117 \\
116\end{array}$ & $\begin{array}{l}10.9 \\
10.4\end{array}$ & $\begin{array}{l}69 \\
69\end{array}$ & $\begin{array}{l}9.1 \\
8.7\end{array}$ & $\begin{array}{l}20.6 \\
24.1\end{array}$ & $\begin{array}{l}66.1 \\
68.5\end{array}$ & $\begin{array}{l}64.9 \\
64.2\end{array}$ \\
\hline \multicolumn{15}{|l|}{ Shift work } \\
\hline $\begin{array}{l}\text { Followed subjects } \\
\text { Dropouts }\end{array}$ & $\begin{array}{l}554 \\
115\end{array}$ & $\begin{array}{l}33.4 \\
34.8\end{array}$ & $\begin{array}{l}8.4 \\
8.9\end{array}$ & $\begin{array}{l}13.5 \\
13.5\end{array}$ & $\begin{array}{l}7.9 \\
7.5\end{array}$ & $\begin{array}{l}22.3 \\
22.1\end{array}$ & $\begin{array}{l}2.7 \\
2.7\end{array}$ & $\begin{array}{l}119 \\
118\end{array}$ & $\begin{array}{r}10.4 \\
9.3\end{array}$ & $\begin{array}{l}70 \\
71\end{array}$ & $\begin{array}{l}8.9 \\
9.3\end{array}$ & $\begin{array}{l}23.7 \\
26.9\end{array}$ & $\begin{array}{l}66.4 \\
59.6\end{array}$ & $\begin{array}{l}70.6 \\
64.0\end{array}$ \\
\hline
\end{tabular}

a Body mass index $=$ height $(\mathrm{cm}) /$ weight $(\mathrm{kg})^{2}$.

b $1 \mathrm{~mm} \mathrm{Hg} \approx 0.133 \mathrm{kPa}$.

- Habitual drinker: drinking more than 5 times per week.

" Lack of leisure-time sport: participation less than once per week. 
Table 3. Base-line characteristics according to work conditions in 1990 and 1995

\begin{tabular}{|c|c|c|c|c|c|c|c|c|c|c|c|c|c|c|}
\hline \multirow[t]{2}{*}{$\begin{array}{l}\text { Type of work } \\
\text { schedule in } \\
\text { 1990-1995 }\end{array}$} & \multirow[t]{2}{*}{$\mathrm{N}$} & \multicolumn{2}{|c|}{ Age (years) } & \multicolumn{2}{|c|}{$\begin{array}{l}\text { Length of } \\
\text { employment } \\
\text { (years) }\end{array}$} & \multicolumn{2}{|c|}{$\begin{array}{l}\text { Body mass } \\
\text { index }\end{array}$} & \multicolumn{2}{|c|}{$\begin{array}{c}\text { Systolic blood } \\
\text { pressure } \\
(\mathrm{mm} \mathrm{Hg})\end{array}$} & \multicolumn{2}{|c|}{$\begin{array}{c}\text { Diastolic blood } \\
\text { pressure } \\
\text { (mm Hg } \text { (mb }^{b}\end{array}$} & \multirow[t]{2}{*}{$\begin{array}{l}\text { Habitual } \\
\text { drinking } \\
(\%)\end{array}$} & \multirow[t]{2}{*}{$\begin{array}{l}\text { Current } \\
\text { smoking } \\
(\%)\end{array}$} & \multirow{2}{*}{$\begin{array}{c}\text { Lack of } \\
\text { leisure- } \\
\text { time } \\
\text { sport }(\%\end{array}$} \\
\hline & & Mean & SD & Mean & $\mathrm{SD}$ & Mean & SD & Mean & SD & Mean & SD & & & \\
\hline Day-day & 924 & 35.5 & 8.0 & 16.0 & 7.9 & 22.1 & 2.5 & 117 & 11 & 69 & 9.2 & 21.1 & 66.0 & 64.3 \\
\hline Day-shift & 73 & 33.7 & 8.0 & 13.3 & 6.9 & 22.2 & 2.7 & 119 & 10.5 & 70 & 8.6 & 15.1 & 63.0 & 57.5 \\
\hline Shiff-day & 180 & 33.2 & 8.0 & 13.6 & 7.1 & 22.4 & 2.5 & 119 & 9.5 & 70 & 8.5 & 21.7 & 65.6 & 67.8 \\
\hline Shift-shift & 374 & 33.5 & 8.5 & 13.4 & 7.6 & 22.2 & 2.7 & 118 & 10.8 & 70 & 9.1 & 22.7 & 66.3 & 70.1 \\
\hline
\end{tabular}

a Body mass index $=$ height $(\mathrm{cm}) /$ weight $(\mathrm{kg})^{2}$. $\quad$ в $1 \mathrm{~mm} \mathrm{Hg} \approx 0.133 \mathrm{kPa}$. ' Habitual drinker: drinking more than 5 times per week.

d Lack of leisure-time sport: participation less than once per week.

Table 4. Cumulative incidence of hypertension by type of work schedule $(1990-1995) .(95 \% \mathrm{Cl}=95 \%$ confidence interval)

\begin{tabular}{|c|c|c|c|c|}
\hline \multirow[t]{2}{*}{ Age in 1990} & \multirow[t]{2}{*}{$\begin{array}{c}\text { Subjects } \\
\text { (N) }\end{array}$} & \multicolumn{3}{|c|}{$\begin{array}{c}\text { Cumulative incidence } \\
\text { of hypertension }\end{array}$} \\
\hline & & $N$ & $\%$ & $95 \% \mathrm{Cl}$ \\
\hline \multicolumn{5}{|l|}{$18-29$ years } \\
\hline Day-day & 228 & 8 & 3.5 & $1.1-5.9$ \\
\hline Day-shift & 25 & 1 & 4.0 & $0-11.7$ \\
\hline Sift-day & 65 & 2 & 3.1 & $1.1-7.3$ \\
\hline Shift-shift & 134 & 16 & 11.9 & $6.4-17.4$ \\
\hline All & 452 & 27 & 6.0 & $3.8-8.2$ \\
\hline \multicolumn{5}{|l|}{ so-39 years } \\
\hline Day-day & 339 & 21 & 6.2 & $3.6-8.8$ \\
\hline Day-shift & 28 & 0 & 0.0 & $0-0$ \\
\hline Sift-day & 70 & 4 & 5.7 & $0.3-11.1$ \\
\hline Shift-shift & 131 & 4 & 3.1 & $0.1-6.1$ \\
\hline All & 568 & 29 & 5.1 & $3.3-6.9$ \\
\hline \multicolumn{5}{|l|}{$40-49$ years } \\
\hline Day-day & 357 & 30 & 8.4 & $5.5-11.3$ \\
\hline Day-shift & 20 & 3 & 15.0 & $0-30.6$ \\
\hline Sift-day & 45 & 8 & 17.8 & $6.6-29.0$ \\
\hline Shift-shift & 109 & 12 & 11.0 & $5.1-16.9$ \\
\hline All & 531 & 53 & 10.0 & $7.4-12.6$ \\
\hline \multicolumn{5}{|c|}{ All ages combined } \\
\hline Day-day & 924 & 59 & 6.4 & $4.8-8.0$ \\
\hline Day-shift & 73 & 4 & 5.5 & $0.3-10.7$ \\
\hline Sift-day & 180 & 14 & 7.8 & $3.9-11.7$ \\
\hline Shift-shift & 374 & 32 & 8.6 & $5.8-11.4$ \\
\hline All & 1551 & 109 & 7.0 & $5.7-8.3$ \\
\hline
\end{tabular}

continuous variables, and drinking habit was used as a categorized variable (drinking less than 5 times per week or drinking 5 or more times per week).

\section{Results}

Among the 1551 subjects, we found 109 displaying an onset of hypertension. The cumulative incidence of hypertension for all of the subjects was $7.0 \%$ (table 4 ). With all the age groups combined, we did not find any difference in the cumulative incidence between the 4 groups according to the work conditions. However, when we compared the cumulative incidence between the 4 groups in each 10-year age category, different results were
Table 5. Relative risks (RR) for hypertension among the shift workers on different work schedules (1990-1995) according to multiple logistic analyses for each age category. $(\mathrm{BMI}=$ body mass index, SBP = systolic blood pressure, drinking = drinking more than 5 times per week or not, $95 \% \mathrm{Cl}=95 \%$ confidence interval)

\begin{tabular}{|c|c|c|c|c|}
\hline \multirow[t]{2}{*}{ Age } & \multicolumn{2}{|c|}{ Adjustment for age } & \multicolumn{2}{|c|}{$\begin{array}{l}\text { Adjustment for } \\
\text { age, BMI, SBP, drinking }\end{array}$} \\
\hline & $R R$ & $95 \% \mathrm{Cl}$ & $\mathrm{RR}$ & $95 \% \mathrm{Cl}$ \\
\hline \multicolumn{5}{|l|}{$18-29$ years } \\
\hline Day-day & 1 & & 1 & \\
\hline Day-shift & 1.3 & $0.015-10.4$ & 1.3 & $0.15-11.3$ \\
\hline Sift-day & 1.0 & $0.20-4.59$ & 1.1 & $0.22-5.4$ \\
\hline Shift-shift & 4.0 & $1.67-9.67$ & 3.6 & $1.41-9.1$ \\
\hline \multicolumn{5}{|l|}{$30-39$ years } \\
\hline Day-day & 1 & & 1 & \\
\hline Sift-day & 1.1 & $0.37-3.28$ & 0.9 & $0.28-2.9$ \\
\hline Shift-shift & 0.6 & $0.19--1.69$ & 0.4 & $0.14-1.4$ \\
\hline \multicolumn{5}{|l|}{$40-49$ years } \\
\hline Day-day & 1 & & 1 & \\
\hline Day-shift & 2.0 & $0.56-7.47$ & 2.6 & $0.57-12.2$ \\
\hline Sift-day & 2.5 & $1.08-5.91$ & 2.4 & $0.93-6.0$ \\
\hline Shift-shift & 1.4 & $0.69-2.80$ & 1.2 & $0.55-2.7$ \\
\hline
\end{tabular}

shown between the groups. Among the workers aged $18-29$ years, the cumulative incidence of hypertension among the "shift-shift" workers, who did shift work in both 1990 and 1995, was the highest (11.9\%) and the cumulative incidence of the other 3 groups was almost the same, showing $3.0-4.0 \%$. For the 30 - to 39 -year-olds, we did not find any difference among the 4 groups. For the workers aged $40-49$ years, the cumulative incidence of the "shift-day" workers, who transferred from shift work to day work during the observation period, was the highest $(17.8 \%)$, followed by "day-shift" workers, "shiftshift" workers, and "day-day" workers.

We analyzed the relative risks of hypertension for the 3-shift workers in a multiple logistic analysis (table 5). When the group of "shift-shift" workers was compared with the group of "day-day" workers in the $18-29$ year age group, the relative risk was significantly high, 4.0 after adjustment for age and 3.6 after adjustment for age and other confounding factors, such as BMI, systolic 
blood pressure, and drinking habit. The risks of the group of "day-shift" workers and "shift-day" workers were almost the same as that of the "day-day" workers. In the 30- to 39-year age group we did not find any higher risk of hypertension for the shift workers. Among the subjects aged 40-49 years, we could not find any higher risk among the "shift-shift" workers. When the group of the "shift-day" workers was compared with the "dayday" workers, the relative risk was significantly high, 2.5 after adjustment for age only. Although the relative risk of that group was diminished when the other confounding factors were allowed in the model, it was suggested that the workers who quit shift work had a higher risk of hypertension compared with the other groups.

\section{Discussion}

The purpose of the present study was to determine the influence of shift work on blood pressure. It has been recognized that shift work may be a risk factor for ischemic heart disease in some recent cohort studies $(1-9)$. If irregular workhours increase coronary risk, its mechanism is not clear, and there is no study that indicates the effect of shift work on blood pressure. In the studies of the effect of shift work on health, there were some major methodological problems regarding selection into shift work and selection out of shift work $(19,20)$. Some studies suggested that the workers who dropped out of shift work had a higher risk of ischemic heart disease than the workers who continued shift work $(1,3)$. The longer the workers stay on their jobs, the greater the possibility may be of their being rotated when their physical condition is taken into account. Hence we analyzed data with stratification by age and distinguished the workers who had continued 3-shift work from those who had stopped shift work.

In the younger age group, under 30 years of age, the cumulative incidence of hypertension among the workers who did 3-shift work from the base line to the end point was about 3 times higher than that of the workers who continued day work. The relative risk of the former compared with that of the latter was significantly high after adjustment for confounding factors such as BMI, age, habitual drinking, and base-line blood pressure. Because the younger age group had less opportunity to be rotated according to their physical condition, it is suggested that 3-shift work has an influence on blood pressure. Among the workers 30-39 and 40-49 years of age, we could not find a high risk of hypertension for the workers who had continued shift work. However, we found a relatively high risk of hypertension for the workers aged $40-49$ years who converted from shift work to day work (when compared with the others). Although we could not investigate the reasons for their removal from shift work, the workers who continued shift work until an older age may have been healthier than the others.

Although our findings suggest that shift work affects the onset of hypertension, we have to consider some factors which might influence the results of this study, such as the misclassification of work conditions and the misdiagnosis of hypertension, the previous occupational history of the workers, and the difference between the jobs and tasks of the 3-shift and day workers. We thought that the misclassification of the work conditions was few, since the work schedules were asked directly from the subjects in a questionnaire administered at the time of the base-line and end-point examinations. We also thought that there were few misdiagnoses since hypertension was diagnosed according to the criteria mentioned in the Methods section. Moreover, only workers who had $\geq 4$ annual health examinations were included in the study.

We could not allow the length of exposure of irregular shifts into the analyses because the previous occupational histories of the workers were not known. However, since most of the employees of this factory were employed immediately after graduation, they did not have other occupational histories. In addition, because there were few workers who changed from fixed day work to 3-shift work, we assumed that the length of exposure to irregular shifts among the 3-shift workers in 1990 was almost equal to their time in employment. We did not take into account the difference in jobs and tasks, for example, physical activity between 3-shift workers and day workers. There are some cifferences in the jobs of 3 -shift workers and day workers. However, because many of the manufacturing processes were automated, it seemed that the physical activity did not significantly differ between the day workers and 3-shift workers. Hence, although there were a few insufficiencies in the information on occupational history and work load, we conclude that an association between 3-shift work and hypertension is suggested by our study.

Some studies on the ambulatory measurement of blood pressure among shift workers indicate that the elevation of blood pressure among shift and night workers is caused by differences in the diurnal-nocturnal blood pressure rhythm and that it does not always cause definite hypertension $(21-25)$. Our results suggested a chronic effect on the blood pressure of shift workers. In order to determine whether high blood pressure at younger ages causes hypertension at their age or not, a longer observation period is required.

\section{References}

1. Koller M, Kundi M, Cervinka R. Field studies of shift work at an Austrian oil refinery, 1: health and psychosocial wellbeing 
of workers who drop out of shiftwork. Ergonomics 1978;21:835-47.

2. Koller M. Health risks related to shift work, an example of time-contingent effects of long-term stress. Int Arch Occup Environ Health 1983;53:59-75.

3. Angersbach D, Knauth P, Loskant H, Karvonen MJ, Undeutsh K, Ruftenfranz J. A retrospective cohort study comparing complaints and diseases in day and shift workers. Int Arch Occup Environ Health 1980;45:127—40.

4. Åkerstedt T, Knutsson A, Alfredsson L, Theorell T. Shift work and cardiovascular disease. Scand $\mathrm{J}$ Work Environ Health 1984;10:409-14.

5. Alfredsson L, Karasek R, Theorell T. Myocardial infarction risk and psychosocial work environment: An analysis of the male Swedish working force. Soc Sci Med 1982;16:463-7.

6. Alfredsson L, Theorell T. Job characteristics of occupations and myocardial infarction risk: effect of possible confounding factors. Soc Sci Med 1983;17:1497-503.

7. Alfredsson L, Spetz CL, Theorell T. Type of occupation and near-future hospitalization for myocardial infarction and some other diagnoses. Int J Epidemiol 1985;14:378-88.

8. Knutsson A, Åkerstedt T, Jonsson BG, Orth-Gomer K. Increased risk of ischemic heart disease in shift workers. Lancet 1986; 12:89-92.

9. Tenkanen L, Sjöblom T, Kalimo R, Alikoski T, Härmä M. Shift work, occupation and coronary heart disease over 6 years of follow-up in the Helsinki Heart Study. Scand J Work Environ Health 1997;23:257-65.

10. Fouriaud C, Jacquinet-Salord MC, Degoulet P, Aimé F, Lang $T$, Laprugne $J$, et al. Influence of socioprofessional conditions on blood pressure levels and hypertension control. Am J Epidemiol 1984;120:72-86.

11. Orth-Gomér K. Intervention on coronary risk factors by adapting a shift work schedule to biologic rhythmicity. Psychosom Med 1983;45:407-15.

12. Peacock B, Glube R, Miller M, Clune P. Police officers' responses to 8 and 12 hour shift schedules. Ergonomics 1983;26:479-93.

13. Thelle DS, Førde OH, Try K, Lehmann EH. The Troms $\varnothing$ heart study: methods and main results of the cross-sectional study. Acta Med Scand 1976;200:107-18.

14. Theorell T, Åkerstedt T. Day and night shift work: changes in cholesterol, uric acid, glucose and potassium in serum and in circadian patterns of urinary catecholamine excretion. Acta Med Scand 1976;200:47-53.

15. Knutson A, Andersson H, Berglund U. Serum lipoproteins in day and shift workers: a prospective study. $\mathrm{Br} \mathrm{J}$ Ind Med 1990;47:132-4.

16. Knutsson A, Åkerstedt T, Jonsson BG. Prevalence of risk factors for coronary artery disease among day and shift workers. Scand J Work Environ Health 1988;14:317-21.

17. Romon M, Nuttens MC, Fievet C, Pot P, Bard JM, Furon D, et al. Increased triglyceride levels in shift workers. Am J Med 1992;93:259-62.

18. Lennernäs $\mathrm{M}$, Åkerstedt $\mathrm{T}$, Hambræus L. Nocturnal eating and serum cholesterol of three-shift workers. Scand J Work Environ Health 1994;20:401-6.

19. Rutenfranz J, Colquhoun WP, Knauth P, Ghata JN. Biomedical and psychosocial aspects of shift work: a review [review]. Scand J Work Environ Health 1977;3:165-82.

20. Kristensen TS. Cardiovascular diseases and the work environment: a critical review of the epidemiologic literature on nonchemical factors [review]. Scand J Work Environ Health $1989 ; 15: 165-79$.

21. Clark LA, Denby L, Pregibon D, Harshfield GA, Pickering TG, Blank S, et al. A quantitative analysis of the effects of activity and time of day on the diurnal variations of blood pressure. J Chronic Dis 1987;40:671—-81.

22. Baumgart $P$, Walger $P$, Fuchs G, Eiff MV, Vetter H, Rahn KH. Diurnal variations of blood pressure in shift workers during day and night shifts. Int $J$ Occup Environ Health 1989:61:463-6.

23. Chau NP, Mallion JM, Gaudemaris R, Ruche E, Siche JP, Pelen $\mathrm{O}$, et al. Twenty-four-hour ambulatory blood pressure in shift workers. Circulation 1989;80:341-7.

24. Hakola T, Härmä MI, Laitinen JT. Circadian adjustment of men and women to night work. Scand J Work Environ Health 1996;22:133-8.

25. Cesana G, Ferrario M, Sega R, Milesi C, De Vito G, Mancia $\mathrm{G}$, et al. Job strain and ambulatory blood pressure levels in a population-based employed sample of men from northern Italy. Scand J Work Environ Health 1996;294-305.

Received for publication: 15 December 1997 